\title{
The Impact of Age and Gender Diversity on Oganisational Commitment
}

\author{
Raymond Toga* \\ Nombali P Qwabe \\ Themba Q Mjoli \\ Department of Industrial Psychology, University of Fort Hare, \\ Private Bag X1314, Alice, 5700, South Africa \\ *Email: raytoga@gmail.com
}

\author{
Doi:10.5901/mjss.2014.v5n1p657
}

\begin{abstract}
Establishing the relationship between managers and employees' age and gender differences and the level of commitment could be of benefit to the organisations in the sense that these demographic differences can be used as predictors of employees' organisational commitment. The main purpose of the study was specifically to examine the two relational demographic differences (age and gender differences) between manager and employee and the role they play on employees' organisational commitment. A raosoft sample size calculator was used to calculate the recommended sample size; therefore an interval or systematic random sample of 100 lower level employees. A self designed biographical and occupational data questionnaire, and to measure Organisational Commitment, Meyer and Allen (1997) which consists of 18 - item Likert-type rating scale was used. Data analysis was done by means of descriptive statistics, analysis of variance and the t-test. The results indicated a significant differences in the unexpected directions in affective commitment and continuance commitment between male employees supervised by male managers and male employees supervised by female managers; male employees were found to have higher levels of affective and continuance commitment when supervised by female managers. Female employees were found to have a higher level of normative commitment when supervised by male managers than when supervised by female managers which was also in the unexpected direction. Managers should be encouraged to apply the principles of workforce diversity in personnel selection and continue to provide diversity training in the workplace so as to dispel any vestiges of resistance to diversity which may have accounted for the partial support for the similarity/attraction paradigm that was demonstrated by the results. This study provides insights and information on age and gender differences as components of diversity which play an important role in the quality of manager-employee relationship in an organisation.
\end{abstract}

\section{Introduction}

Globalisation in the workplace has brought about more and more diverse individuals with different work ethics, deepseated attitudes and opposing perspectives. There is no one definition of diversity; however, there has been considerable agreement on the components of diversity, that is, diversity based on age, gender, religion and race which can all affect workplace relationships (Dessler, 2005 ; Fajana, 2009). With such great diversity within organisations now, one is left to wonder how these different individuals are to be managed and which manager would be ideal to manage them in a way that will encourage organisational commitment and achievement of organisational objectives (Owoyemi, Elegbede \& Gbajumo-Sheriff 2011). Studies conducted on age and gender diversity have been rooted on three theories that enable one to understand the impact of age and gender diversity on organisational commitment as well as the organisation as a whole. These theories are: (i) the social roles theory of Eagly (1987); (ii) the social identity theory of Tajfel and Turner (1986), and (iii) the similarity-attraction paradigm of Byrne (1971).

The study mainly focused on age and gender differences as components of diversity which play a role in the quality of manager-employee relationship in an organisation. A number of studies previously done show that age and gender differences can affect the quality of an employee's work and work attitudes and also the manager-employee relations. The main aim of the study therefore was specifically to examine the two relational demographic differences (age and gender differences) between manager and employee and the role they play on employee organisational commitment. 


\subsection{Statement of the problem}

Age and gender differences are ever-increasing and unavoidable features of the workplace among managers and employees in the globalised world of today (Greenberg \& Baron, 2010). It is therefore important to find out what the effects of such age and gender differences may be on the job performance and work attitudes of employees. This study therefore set out to investigate the effects of age and gender differences between managers and their employees may be on organisational commitment. The study was mainly based on the theoretical approaches mentioned in the literature review section.

The first set of theory argues, on the one hand, that similarity promotes compatibility, interpersonal attraction, and identity reinforcement; while on the other hand, dissimilarity creates incompatibility, disorder, and alienation. Based on this theory, the study therefore investigated whether similarity between managers and employees in age and gender is associated with high organisational commitment while dissimilarity between managers and employees in age and gender is associated with low organisational commitment. The second set of theory, the theory of social roles (Eagly, 1987) argues that society prescribes different roles to members of different groups and that such roles generally coincide with power and status norms. Normally society ascribes the managerial role to men while women are supposed to be subordinates and ascribes the managerial role to older persons while younger persons are supposed to be subordinates.

According to this theory members of society (including employees) will generally be happy to be led by men and will accordingly show commitment to the organisation they work for. If their managers are women, on the other hand, employees will generally feel uncomfortable and will accordingly not be committed to the organisation they work for. It can likewise be expected that employees whose managers are older than them will be comfortable and therefore committed to the organisation they work for while employees who are managed by young managers will be uncomfortable and less committed to the organisation they work for. Based on these theories, the study investigated whether employees reporting to male or older managers showed a higher level of organisational commitment than employees reporting to younger or female managers.

In light of the discussion above, the objectives of the study were:

1. To determine whether the levels of organisational commitment of an employee differ depending on the managers and employee's age and gender.

2. A sub-objective was to test the validity of the similarity-attraction paradigm of Byrne (1971), the social identity theory of Tajel and Turner (1986), and the social roles theories of Eagly (1987) in the Buffalo City Metropolitan Area.

3. A further sub-objective was to provide guidelines that could aid in both the management of organisational commitment and the assignment of employees to work teams.

\subsection{Similarity hypotheses}

These three hypotheses are based on the similarity-attraction paradigm of Byrne (1971) and the social identity theory of Tajfel and Turner (1986).

1. Male employees supervised by a male manager have a higher level of organisational commitment than male employees supervised by a female manager.

2. Female employees supervised by a female manager have a higher level of organisational commitment than female employees supervised by a male manager.

3. Employees who have a manager who is of the same age have a higher level of organisational commitment than employees with a manager who is older or younger.

\subsection{Social role or cultural hypotheses}

These two hypotheses are based on the social roles theories of Eagly (1987).

1. Employees managed by a male manager have a higher level of organisational commitment than employees managed by a female manager.

2. Employees managed by an older manager have a higher level of organisational commitment than employees managed by younger or same age managers. 


\section{Literature review}

\subsection{The Social Roles Theory}

The social roles theory (Eagly, 1987) argues that society prescribes different roles to members of different groups and such roles generally coincide with power and status norms. Further, when work roles break with social roles or traditional hierarchies, this conflict can cause discomfort for both the employee and manager (Eagly, 1987). On the one hand, when employees are from an older group than their managers, such employees are more likely to resent and to disrespect their managers. On the other hand, younger managers may defer to older employees and may refrain from exercising their authority in order to avoid discomfort and disapproval. In this study, two demographic relationships break with traditional roles and hierarchies: managers with subordinates older than themselves, and women managing men. This may be because subordinates may be less comfortable in these role-breaking relationships; their organisational commitment level may be affected as well.

\subsection{The Social identity / categorizing theory}

Previous research suggests that most researchers adopt the social identity theory to try to understand the effects of workplace diversity (Northcraft, Polzer, Nale \& Kramer, 1995). In most cases the social identity theory has been used to predict and understand how age and gender diversity influence an employee's attitude and behaviour (Jackson, Joshi, \& Erhardt, 2003). In explaining the effects that age and gender diversity have on an individual's behaviour, the basic argument could be that one's similarity on visible and relatively immutable traits influences one's feelings of identification (Tsui, Egan \& O'Reilly, 1992). Particularly, gender is one obvious example used to illustrate how self-categorisation may increase or decrease the attractiveness of a group to an individual (Hoffman \& Hurst, 1990). During the process of selfcategorisation, individuals classify themselves and others into social categories using attributes such as age, gender or race (Williams \& O'Reilly, 1998). According to Tajfel and Turner (1986), this process allows a person to define him or herself in terms of social identity, and that leads to in-group or out-group distinctions. Moreover, individuals desire to maintain a high level of self-esteem and a positive self-identity (Tajfel, 1981; Tajfel \& Turner, 1986). According to Kramer (1991), individuals may seek to maximize intergroup distinctiveness in order to maintain a positive self-identity thus viewing individuals from other groups as less trustworthy, honest or even co-operative than members of their own group.

\subsection{The similarity/attraction paradigm}

Byrne (1971) developed the similarity/attraction paradigm through a review of previous literature related to similarity and dissimilarity. This paradigm argues that people are more attracted to similar others. "Birds of a feather flock together" is a proverb that best summarises the similarity/attraction paradigm. According to Byrne, Clore and Worchel (1966), similarity in personal attributes is a source of interpersonal attraction and these attributes ranges from attitudes, values, demographic variables, and socioeconomic background, to competence and leisure activities. Geddes and Konrad (2003) state that members of the same demographic group enjoy easier communication, have a faster development of rapport and have a greater perceived likelihood that values and opinions will be validated. If individuals can choose freely, there is a strong tendency for them to select a person that is similar to them (William \& O'Reilly, 1998).

According to Byrne (1971), the similarity/attraction paradigm also supports the view that when group members have similar attributes, stronger cohesiveness between them will result. The homogeneity of groups leads to increased satisfaction and cooperation, and to reduced emotional conflicts (Williams \& O'Reilly, 1998). By contrast, when similarity between members is low; increased or intensified conflict may result, thus reducing individual satisfaction and increasing turnover and work pressure (Tsui \& O'Reilly, 1989). In heterogamous groups, differences between members lead to decreased communication, message distortion, and more errors in communication (Barnlund \& Harland, 1963; Triandis, 1960). For example, Alagna, Reddy, and Collins (1982) demonstrated that mixed-gender groups reported higher levels of conflict and tension and less friendliness than same-sex groups. According to Horwitz (2005), homogeneous teams are likely to be more productive than heterogeneous teams because of the mutual attraction between team members with similar characteristics thus, consistent with social identity/categorisation theory, the similarity/attraction paradigm argues that gender diversity is associated with negative performance outcomes. 


\section{Research Methodology}

\subsection{Research approach}

A quantitative research design was used. The researcher utilised a quantitative approach because, as noted by Leedy (2001), quantitative research design allows the research to answer questions about the relationships between measured variables with the purpose of explaining, predicting and controlling certain phenomena. In addition to that Branche, Durrheim and Painter (2006) also found that findings obtained from quantitative research are generated and the data is objective.

\subsection{Research participants}

The sample was selected from Johnson \& Johnson (Pty) Ltd, FloorWorx Africa (Pty) Ltd, Independent concrete supplies (Pty) Ltd), Nestle, Belly Sweets, Meyer Motors and Motorland factories in Buffalo City Metropolitan Area. The representative sample size of the study was $n=100$. The Raosoft sample size calculator was used to calculate the recommended sample size and this was determined by using a 5\% margin of error; 95\% confidence level and 50\% response distribution. Using a population size of 1000 , the recommended minimum sample size obtained was 278 and due to time and expense constrains, the sample size of 278 but $10 \%$ of the sample of the population was used, which makes it fairly large. Patten (2004), states that lack of bias is the main criterion when evaluating the adequacy of a sample. Patten (2004) also identifies an unbiased sample as one in which every member of a population has an equal opportunity of being selected into the sample. Therefore, an interval or systematic random sampling was used in the study to help ensure the selection of an unbiased sample. To obtain an interval or systematic random sample, employees were selected at equal intervals, starting with a randomly selected employee on the population list. Below is the description of the sample of this study.

\subsection{Measuring Instrument}

A questionnaire was used to collect data. The philosophical thinking of positivism (Newman, 2000) which argues that information can be quantified and make interpretations justified the use of a questionnaire to collect data from the defined sample. The questionnaire consisted of two sections; (i) a self designed biographical and occupational data questionnaire, and (ii) to measure Organisational Commitment, Meyer and Allen (1997) 18-item Likert-scale rating was used.

\subsection{Research procedure}

In administering of the questionnaire, the following procedure was followed: After receiving approval from the Research Committee at the University of Fort Hare for the commencement of the study, the researcher approached the Human Resource Departments of all selected factories in the Buffalo City Metropolitan area, Eastern Cape South Africa to request permission to conduct the study. Permission was granted and visits were made to each factory by the research to leave the questionnaires with the HR officials. A total number of 125 questionnaires were distributed. The researcher asked each of the factories Human Resource department personnel to distribute the questionnaires to every 10th lowerlevel employee in their employment list. To achieve a possible high response rate, it was agreed that the data collection period be a maximum of two weeks.

\subsection{Statistical analysis}

Data was analyzed by means of descriptive statistical analysis. The relationship between the variables was analysed by means of analysis of variance (ANOVA) and the t-test. The researcher also used Cronbach's Coefficient Alpha to assess the reliability of the measuring instruments.

\subsection{Ethical consideration}

Permission was sought and granted by the organisations authority. Voluntary informed consent was sought from the 
participants. In addition, confidentiality was maintained at all times and participants were informed through a letter send via email from HR office which communicated essential information about the research

\section{Findings and Discussion}

\subsection{Hypothesis 1}

The first hypothesis of the study $\left(\mathrm{H}_{0}\right)$ was stated as, "male employees supervised by a male manager do not have a significantly higher level of organisational commitment than male employees supervised by a female manager" and the corresponding alternative hypothesis $\left(\mathrm{H}_{1}\right)$, was that, "male employees supervised by a male manager have a significantly higher level of organisational commitment than male employees supervised by a female manager".

Table 1: Mean and standard deviation results for male employees supervised by male managers and male employees supervised by female managers

\begin{tabular}{|l|c|c|c|c|}
\hline \multicolumn{1}{|c|}{ variables } & Gender (supervisor) & $\mathrm{N}$ & Mean & Std. deviation \\
\hline \multirow{2}{*}{ Affective commitment } & Male & 34 & 17.91 & 1.147 \\
& Female & 20 & 18.55 & 2.259 \\
\hline \multirow{2}{*}{ Continuance commitment } & Male & 34 & 12.63 & 2.414 \\
& Female & 20 & 25.15 & 2.434 \\
\hline \multirow{2}{*}{ Normative commitment } & Male & 34 & 23.09 & 2.894 \\
& Female & 20 & 10.30 & .470 \\
\hline \multirow{2}{*}{ Overall organisational commitment } & Male & 34 & 53.63 & 6.455 \\
& Female & 20 & 54 & 5.163 \\
\hline
\end{tabular}

Table 1.1: The t-test results for male employees supervised by male managers and male employees supervised by female managers

\begin{tabular}{|c|c|c|c|c|c|c|}
\hline & \multicolumn{2}{|c|}{ Lenene's Test for Equality of Variance } & \multicolumn{3}{|c|}{ t-test for Equality of Means } \\
\hline & & $\mathrm{F}$ & Sig. & $\mathrm{t}$ & df & Sig (2-tailed) \\
\hline Affective commitment & $\begin{array}{l}\text { Equal Variance assumed } \\
\text { (Average score) }\end{array}$ & 78.000 & .000 & -2.668 & 52 & .010 \\
\hline & Equal variance not assumed & & & -2.032 & 19.000 & 0.56 \\
\hline $\begin{array}{l}\text { Continuance } \\
\text { commitment }\end{array}$ & $\begin{array}{l}\text { Equal variance assumed } \\
\text { (Average score) } \\
\text { Equal variance not assumed }\end{array}$ & 7.680 & .008 & $\begin{array}{l}-51.196 \\
-39.000\end{array}$ & $\begin{array}{c}52 \\
19.000\end{array}$ & $\begin{array}{l}.000 \\
.000\end{array}$ \\
\hline Normative commitment & $\begin{array}{l}\text { Equal variance assumed } \\
\text { (Average score) } \\
\text { Equal variance not assumed }\end{array}$ & 5.478 & .023 & $\begin{array}{l}36.205 \\
47.393\end{array}$ & $\begin{array}{c}52 \\
33.000\end{array}$ & $\begin{array}{l}.000 \\
.000\end{array}$ \\
\hline $\begin{array}{l}\text { Overall organisational } \\
\text { commitment }\end{array}$ & $\begin{array}{l}\text { Equal variance assumed } \\
\text { (Average score) } \\
\text { Equal variance not assumed }\end{array}$ & 7.680 & .008 & $\begin{array}{l}1.313 \\
1.000\end{array}$ & $\begin{array}{c}52 \\
19.000\end{array}$ & .195 \\
\hline
\end{tabular}

Tables 1 and 1.1 results indicate that there were 34 male employees supervised by male supervisors with an effective commitment mean score of 17.91 and a standard deviation of 1.15 . There were 20 male employees supervised by female supervisors and they had an affective commitment mean score of 18.55 and a standard deviation of 18.55. The results indicated that there was a significant difference on the level of affective commitment between male employees supervised by male managers and those male employees supervised by female managers $(t=-2.668 ; d f=52 ; p<0.01)$. This leads to a rejection of the alternative hypothesis and acceptance of the null hypothesis.

The results show that there were 34 male employees supervised by male supervisors with a continuance commitment mean score of 12.63 and a standard deviation of 2.26. There were also 20 male employees supervised by female supervisors and they had a continuance commitment mean score of 25.15 and a standard deviation of 2.43. The results show that there is a significant difference in the level of continuance commitment. Male employees supervised by male managers have a significantly lower level of continuance commitment than those supervised by female managers $(t=-39.000 ; d f=19 ; p<=0.00)$. This leads to acceptance of the null hypothesis. 
The results also indicate that there were 34 male employees supervised by male supervisors with a normative commitment mean score of 23.09 and a standard deviation of 2.89. There were also 20 male employees supervised by female supervisors and they had a normative commitment mean score of 10.3 and a standard deviation of 0.47 . The results show that there is a significant difference in the level of normative commitment between male employees supervised by a male manager and male employees supervised by a female manager $(t=47.393 ; \mathrm{df}=33 ; p<=0.000$ ). This leads to rejection of the null hypothesis and acceptance of the alternative hypothesis.

The results indicate that there were 34 male employees supervised by male supervisors with an overall organisational commitment mean score of 53.63 and a standard deviation of 6.46 . There were also 20 male employees supervised by female supervisors and they had an overall organisational commitment mean score of 54.00 and a standard deviation of 5.16. The results show that there is no significant difference in the level of overall organisational commitment between male employees supervised by a male manager and male employees supervised by a female manager $(t=1.313 ; d f=52 ; p<=0.330)$. This leads to acceptance of the null hypothesis.

\subsection{Hypothesis 2}

The second hypothesis of the study $\left(\mathrm{H}_{0}\right)$ was stated as, "female employees supervised by a female manager do not have a significantly higher level of organisational commitment than female employees supervised by a male manager" and the corresponding alternative hypothesis $\left(\mathrm{H}_{1}\right)$, was that, "female employees supervised by a female manager have a significantly higher level of organisational commitment than female employees supervised by a male manager".

Table 2: Mean and standard deviation results for female employees supervised by female managers and female employees supervised by male supervisors

\begin{tabular}{|l|c|c|c|c|}
\hline \multicolumn{1}{|c|}{ variables } & Gender (supervisor) & $\mathrm{N}$ & Mean & Std. deviation \\
\hline \multirow{2}{*}{ Affective commitment } & Male & 18 & 17.82 & 1.362 \\
& Female & 28 & 19 & 1.455 \\
\hline \multirow{2}{*}{ Continuance commitment } & Male & 18 & 12.5 & .745 \\
& Female & 28 & 25.67 & .485 \\
\hline \multirow{2}{*}{ Normative commitment } & Male & 18 & 23.25 & 2.533 \\
& Female & 28 & 10.33 & .485 \\
\hline \multirow{2}{*}{ Overall organisational commitment } & Male & 18 & 53.57 & 4.64 \\
& Female & 28 & 55 & 2.425 \\
\hline
\end{tabular}

Table 2.1: The t-test results for female employees supervised by female managers and female employees supervised by male managers

\begin{tabular}{|c|c|c|c|c|c|c|}
\hline & \multicolumn{2}{|c|}{ Lenene's Test for Equality of Variance } & \multicolumn{3}{|c|}{ t-test for Equality of Means } \\
\hline & & $\mathrm{F}$ & Sig. & $\mathrm{t}$ & df & Sig (2-tailed) \\
\hline $\begin{array}{l}\text { Affective } \\
\text { commitment }\end{array}$ & $\begin{array}{l}\text { Equal Variance assumed } \\
\text { (Average score) } \\
\text { Equal variance not assumed }\end{array}$ & 53.295 & .000 & $\begin{array}{l}3.637 \\
3.081\end{array}$ & \begin{tabular}{|c|}
44 \\
20.357
\end{tabular} & $\begin{array}{l}.001 \\
.006\end{array}$ \\
\hline $\begin{array}{l}\text { Continuance } \\
\text { commitment }\end{array}$ & $\begin{array}{l}\text { Equal variance assumed } \\
\text { (Average score) } \\
\text { Equal variance not assumed }\end{array}$ & 2.751 & .104 & $\begin{array}{l}4.561 \\
4.021\end{array}$ & $\begin{array}{c}44 \\
27.000\end{array}$ & $\begin{array}{l}.001 \\
.004\end{array}$ \\
\hline $\begin{array}{l}\text { Normative } \\
\text { commitment }\end{array}$ & $\begin{array}{l}\text { Equal variance assumed } \\
\text { (Average score) } \\
\text { Equal variance not assumed }\end{array}$ & 2.751 & .104 & $\begin{array}{l}-21.561 \\
-27.000\end{array}$ & $\begin{array}{c}44 \\
27.000 \\
\end{array}$ & $\begin{array}{l}.000 \\
.000\end{array}$ \\
\hline \begin{tabular}{|l|} 
Overall \\
organisational \\
commitment
\end{tabular} & $\begin{array}{l}\text { Equal variance assumed } \\
\text { (Average score) } \\
\text { Equal variance not assumed }\end{array}$ & 2.751 & .104 & $\begin{array}{l}.799 \\
1.000\end{array}$ & $\begin{array}{c}44 \\
27.000 \\
\end{array}$ & $\begin{array}{l}.429 \\
.326\end{array}$ \\
\hline
\end{tabular}

From table 2 and 2.1 the results indicate that there were 28 female employees supervised by female supervisors with an affective commitment mean score of 19 and a standard deviation of 1.46. There were also 18 female employees supervised by male supervisors and they had an affective commitment mean score of 17.82 and a standard deviation of 1.36. The results show that there is a significant difference in the level of effective commitment. Female employees 
supervised by a female manager have a significantly higher level of affective commitment than female employees supervised by a male manager $(t=3.081 ; d f=20.36 ; p<=0.006)$. This leads to acceptance of the alternative hypothesis.

The results also indicate that there were 28 female employees supervised by female supervisors with a continuance commitment mean score of 25.67 and a standard deviation of 0.49 . There were also 18 female employees supervised by male supervisors and they had a continuance commitment mean score of 12.5 and a standard deviation of 0.75. The results show that there is a significant difference in the level of continuance commitment. Female employees supervised by a female manager have a significantly higher level of continuance commitment than female employees supervised by a male manager $(t=4.021 ; \mathrm{df}=27 ; \mathrm{p}<=0.004)$. This leads to acceptance of the alternative hypothesis.

The results also show that there were 28 female employees supervised by female supervisors with a normative commitment mean score of 10.33 and a standard deviation of 0.49 . There were also 18 female employees supervised by male managers and they had a normative commitment mean score of 23.25 and a standard deviation of 2.53. Female employees supervised by female managers have a significantly lower level of normative commitment than female employees supervised by a male manager $(t=-21.56 ; d f=44 ; p<=0.000)$. This leads to acceptance of the null hypothesis.

The results also show that there were 28 female employees supervised by female managers with an overall organisational commitment mean score of 55 and a standard deviation of 2.43.There were also 18 female employees supervised by male managers and they had an overall organisational commitment mean score of 53.57 and a standard deviation of 4.64. Female employees supervised by female managers do not have a significantly higher level of overall organisational commitment than female employees supervised by male managers $(t=1.000 ; d f=27 ; p<=0.326$ ). This leads to acceptance of the null hypothesis.

\subsection{Hypothesis 3}

The third hypothesis of the study $\left(\mathrm{H}_{0}\right)$ was stated as, "employees who have a manager who is of the same age do not have a significantly higher level of organisational commitment than employees with a manager who is older or younger" and the corresponding alternative hypothesis $\left(\mathrm{H}_{1}\right)$ was that, "Employees who have a manager who is of the same age have a significantly higher level of organisational commitment than employees with a manager who is older or younger".

Table 3: Mean and standard deviation results for employees supervised by managers who are of the same age and employees supervised by managers who are younger

\begin{tabular}{|l|c|c|c|c|}
\hline \multicolumn{1}{|c|}{ variables } & Gender (supervisor) & $\mathrm{N}$ & Mean & Std. deviation \\
\hline \multirow{2}{*}{ Affective commitment } & Male & 32 & 18.32 & 1.101 \\
& Female & 68 & 18.07 & 1.489 \\
\hline \multirow{2}{*}{ Continuance commitment } & Male & 32 & 16 & 6.960 \\
& Female & 68 & 15.48 & 5.717 \\
\hline \multirow{2}{*}{ Normative commitment } & Male & 32 & 19.4 & 6.569 \\
& Female & 68 & 20.19 & 5.921 \\
\hline \multirow{2}{*}{ Overall organisational commitment } & Male & 32 & 53.5 & 14.630 \\
& Female & 68 & 53.75 & 13.127 \\
\hline
\end{tabular}

Table 3.1: The t-test results for employees supervised by managers who are of the same age and employees supervised by managers who are younger or older

\begin{tabular}{|c|c|c|c|c|c|c|}
\hline & \multicolumn{2}{|c|}{ Lenene's Test for Equality of Variance } & \multicolumn{3}{|c|}{ t-test for Equality of Means } \\
\hline & & $\mathrm{F}$ & Sig. & $\mathrm{t}$ & df & Sig (2-tailed) \\
\hline Affective commitment & $\begin{array}{l}\text { Equal Variance assumed } \\
\text { (Average score) }\end{array}$ & .61 & .805 & -.118 & 98 & .907 \\
\hline & Equal variance not assumed & & & -.113 & 55.465 & 910 \\
\hline Continuance commitment & \begin{tabular}{|l|} 
Equal variance assumed \\
(Average score) \\
Equal variance not assumed
\end{tabular} & 7.694 & .007 & $\begin{array}{l}-1.109 \\
-1.143\end{array}$ & $\begin{array}{c}98 \\
65.760 \\
\end{array}$ & $\begin{array}{l}.270 \\
.257\end{array}$ \\
\hline Normative commitment & \begin{tabular}{|l|} 
Equal variance assumed \\
(Average score) \\
Equal variance not assumed
\end{tabular} & 3.480 & .0 .065 & $\begin{array}{l}1.235 \\
1.256 \\
\end{array}$ & $\begin{array}{c}98 \\
63.381 \\
\end{array}$ & .220 \\
\hline $\begin{array}{l}\text { Overall organisational } \\
\text { commitment }\end{array}$ & \begin{tabular}{|l|} 
Equal variance assumed \\
(Average score) \\
Equal variance not assumed
\end{tabular} & 1.194 & .277 & $\begin{array}{l}-.547 \\
-.479\end{array}$ & $\begin{array}{c}98 \\
45.224 \\
\end{array}$ & $\begin{array}{l}.586 \\
.632\end{array}$ \\
\hline
\end{tabular}


The results in Tables 3 and 3.1 shows that the number of employees who have a manager who is of the same age $(n=32)$, and those with older or younger managers $(n=68)$. Employees supervised by managers who is of the same age had an affective commitment mean score of 18.1 and a standard deviation of 1.10 and employees supervised by older or younger managers had an affective commitment mean score of 18.07 and a standard deviation of 1.49. The results indicated that there was no significant difference in affective commitment between employees supervised by same-age managers and those supervised by older or younger managers $(t=-0.113 ; d f=55.47 ; p<=0.91)$. Hence, the null hypothesis is accepted and the alternative hypothesis rejected.

Employees supervised by managers who is of the same age had a continuance commitment mean score of 16 with a standard deviation of 6.96 and employees supervised by older or younger managers had a continuance commitment mean score of 15.48 with a standard deviation of 5.72. The results indicated that there was no significant difference in continuance commitment between employees supervised by same-age managers and those supervised by older or younger managers $(t=-1.143 ; d f=65.76 ; p<=0.26)$. Hence, the null hypothesis is accepted and the alternative hypothesis rejected.

Employees supervised by managers who is of the same age had a normative commitment mean score of 19.4 and a standard deviation of 6.57 and employees supervised by older or younger managers had a normative commitment mean score of 20.19 and a standard deviation of 5.92. The results indicated that there was no significant difference in normative commitment between employees supervised by same-age managers and those supervised by older or younger managers $(t=1.235 ; d f=98 ; p<=0.220$ ). Hence the null hypothesis is accepted and the alternative hypothesis rejected.

Employees supervised by managers who is of the same age had a mean score of 53.5 and a standard deviation of 14.63 on overall organisational commitment, and employees supervised by older or younger managers had a mean overall organisational commitment score of 53.75 and a standard deviation of 13.13. The results indicated that there was no significant difference in overall organisational commitment between employees supervised by same-age managers and those supervised by older or younger managers ( $t=-0.547 ; \mathrm{df}=98 ; p<=0.586)$. Hence, the null hypothesis is accepted and the alternative hypothesis rejected.

\subsection{Hypothesis 4}

The forth hypothesis of the study $\left(\mathrm{H}_{0}\right)$ was stated as, "employees managed by male manager do not have a significantly higher level of organisational commitment than employees managed by a female manager" and the corresponding alternative hypothesis $\left(\mathrm{H}_{1}\right)$ was that, "employees managed by a male manager have a significantly higher level of organisational commitment than employees managed by a female manager".

Table 4: Mean and standard deviation results for employees supervise by male managers and employees supervised by female managers

\begin{tabular}{|l|c|c|c|c|}
\hline \multicolumn{1}{|c|}{ variables } & Gender (supervisor) & $\mathrm{N}$ & Mean & Std. deviation \\
\hline \multirow{2}{*}{ Affective commitment } & Male & 52 & 18.28 & 1.349 \\
& Female & 48 & 18.13 & 1.806 \\
\hline \multirow{2}{*}{ Continuance commitment } & Male & 52 & 17.06 & 6.538 \\
& Female & 48 & 17.77 & 6.514 \\
\hline \multirow{2}{*}{ Normative commitment } & Male & 52 & 18.76 & 6.537 \\
& Female & 48 & 17.85 & 6.782 \\
\hline \multirow{2}{*}{ Overall organisational commitment } & Male & 52 & 54.1 & 14.434 \\
& Female & 48 & 53.8 & 15.102 \\
\hline
\end{tabular}

Table 4.1: The t-test results for employees supervised by male managers and employees supervised by female managers

\begin{tabular}{|c|l|c|c|c|c|c|}
\hline \multicolumn{2}{|c|}{} & \multicolumn{3}{|c|}{ Lenene's Test for Equality of Variance } & \multicolumn{1}{|c|}{ t-test for Equality of Means } \\
\cline { 3 - 7 } \multicolumn{2}{|c|}{ Affective commitment } & $\mathrm{F}$ & Sig. & $\mathrm{t}$ & $\mathrm{df}$ & Sig (2-tailed) \\
\hline & $\begin{array}{l}\text { Equal Variance assumed } \\
\text { (Average score) } \\
\text { Equal variance not assumed }\end{array}$ & .185 & .668 & .440 & 98 & .661 \\
\hline
\end{tabular}




\begin{tabular}{|l|l|c|c|c|c|c|}
\hline $\begin{array}{l}\text { Continuance } \\
\text { commitment }\end{array}$ & $\begin{array}{l}\text { Equal variance assumed } \\
\text { (Average score) } \\
\text { Equal variance not assumed }\end{array}$ & .668 & .416 & -.618 & 98 & .538 \\
\hline Normative commitment & $\begin{array}{l}\text { Equal variance assumed } \\
\text { (Average score) } \\
\text { Equal variance not assumed }\end{array}$ & 3.601 & .061 & .738 & 98 & .462 \\
\hline $\begin{array}{l}\text { Overall organisational } \\
\text { commitment }\end{array}$ & $\begin{array}{l}\text { Equal variance assumed } \\
\text { (Average score) } \\
\text { Equal variance not assumed }\end{array}$ & 9.687 & .002 & 1.489 & 98.976 & .463 \\
\hline
\end{tabular}

The results in Table 4 and 4.1 indicate that the number of employees managed by male manager is 52 and those managed by female managers are 48 in number. Employees supervised by male managers had an affective commitment mean score of 18.28 and a standard deviation of 1.35 while employees supervised by female managers had an affective commitment mean score of 18.13 and a standard deviation of 1.81. The results indicated that there was no significant difference in affective commitment between employees supervised by male managers and those supervised by female managers ( $t=0.440 ; d f=98 ; p<=0.661)$. This leads to acceptance of the null hypothesis.

Employees supervised by male managers had a continuance commitment mean score of 17.06 and a standard deviation of 6.54 while employees supervised by female managers had a continuance commitment mean score 17.77 and a standard deviation of 6.51. These results indicate that there is no significant difference in continuance commitment between employees supervised by male managers and those supervised by female managers $(t=-0.618$; $d f=98$; $p<0.538)$. Hence, the null hypothesis is accepted and the alternative hypothesis is rejected.

Employees supervised by male managers had a normative commitment mean score of 18.76 and a standard deviation of 6.54 while employees supervised by female managers had a normative commitment mean score of 17.85 and a standard deviation of 6.78 . These results indicate that there was no significant difference in normative commitment between employees supervised by male managers and those supervised by female managers $(t=0.738 ; d f=98 ; p<0.46)$. Hence, the null hypothesis is accepted and the alternative hypothesis rejected.

Employees supervised by male managers had an overall organisational commitment mean score of 54.1 and a standard deviation of 14.43 while employees supervised by female managers had an overall organisation commitment mean score of 53.75 and a standard deviation of 15.10. These results indicate that there is no significant difference in overall organisational commitment between employees supervised by male managers and those supervised by female managers $(t=1.489 ; d f=98 ; p<0.140)$. Hence, the null hypothesis is accepted and the alternative hypothesis rejected.

\subsection{Hypothesis 5}

The firth hypothesis of the study $\left(\mathrm{H}_{0}\right)$ was stated as, "employees managed by older manager do not have a significantly higher level of organisational commitment than employees managed by a younger or same-age manager" and the corresponding alternative hypothesis $\left(\mathrm{H}_{1}\right)$ was that, "employees managed by an older manager have a significantly higher level of organisational commitment than employees managed by a younger or same-age manager".

Table 5: Mean and Standard deviation results for employees supervised by an older manager and employees supervised by a younger or same-age manager

\begin{tabular}{|l|l|c|c|c|}
\hline \multicolumn{2}{|c|}{ Variables } & $\mathrm{n}$ & Mean & Std. deviation \\
\hline \multirow{3}{*}{ Affective commitment } & Same age & 11 & 18.1 & 1.10 \\
& Younger & 32 & 18.13 & 1.727 \\
& older & 57 & 18.43 & 1.076 \\
\hline \multirow{3}{*}{ Continuance commitment } & Same age & 11 & 16 & 6.960 \\
& Younger & 32 & 17.54 & 6.513 \\
& older & 57 & 16.71 & 6.592 \\
\hline \multirow{3}{*}{ Normative commitment } & Same age & 11 & 19.4 & 6.569 \\
& Younger & 32 & 18.3 & 6.537 \\
& older & 57 & 18.71 & 6.294 \\
\hline
\end{tabular}




\begin{tabular}{|l|l|c|c|c|}
\hline Overall organisational & Same age & 11 & 53.5 & 14.63 \\
Commitment & Younger & 32 & 53.972 & 14.777 \\
& older & 57 & 53.86 & 13.97 \\
\hline
\end{tabular}

Table 5.1: The ANOVA results for employees supervised by older managers compared to employees supervised by younger or same-age managers

\begin{tabular}{|c|c|c|c|c|c|c|}
\hline & & Sum of squares & Df & Mean of square & $\mathrm{F}$ & Sig. \\
\hline Affective commitment & $\begin{array}{l}\text { Between groups } \\
\text { Within groups }\end{array}$ & $\begin{array}{c}.141 \\
12.859 \\
\end{array}$ & $\begin{array}{c}2 \\
97\end{array}$ & $\begin{array}{l}.070 \\
.133 \\
\end{array}$ & .531 & .589 \\
\hline Continuance commitment & $\begin{array}{l}\text { Between groups } \\
\text { Within groups }\end{array}$ & $\begin{array}{c}1.245 \\
91.505 \\
\end{array}$ & $\begin{array}{c}2 \\
97 \\
\end{array}$ & $\begin{array}{l}.622 \\
.943 \\
\end{array}$ & .660 & .519 \\
\hline Normative commitment & $\begin{array}{l}\text { Between groups } \\
\text { Within groups }\end{array}$ & $\begin{array}{c}2.012 \\
91.988 \\
\end{array}$ & $\begin{array}{c}2 \\
97\end{array}$ & $\begin{array}{c}1.006 \\
.948\end{array}$ & 1.061 & .350 \\
\hline Overall organisational commitment & $\begin{array}{l}\text { Between groups } \\
\text { Within groups }\end{array}$ & $\begin{array}{c}.082 \\
1.878\end{array}$ & $\begin{array}{c}2 \\
97\end{array}$ & $\begin{array}{l}.041 \\
.019\end{array}$ & 2.122 & .125 \\
\hline
\end{tabular}

Hypothesis 5 was tested by means of Analysis of Variance (ANOVA). The results in Tables 5 and 5.1 shows that 57 employees were supervised by older managers with an affective commitment mean score of 18.43 and a standard deviation of 1.08. Eleven employees were supervised by same-age managers with an affective commitment mean score of 18.1 and a standard deviation of 1.10 and 32 employees were supervised by younger managers with an affective commitment mean score of 18.13 and a standard deviation of 1.73. The results indicated that there is no significant difference in affective commitment among employees supervised by same-age, younger or older managers ( $\mathrm{F}=0.531$; $d f=2 / 97 ; p<0.60)$. This leads to acceptance of the null hypothesis.

The results in tables also show that 57 employees were supervised by older managers with a continuance commitment mean score of 16.71 and a standard deviation of 6.59. Eleven employees were supervised by same-age managers with a continuance commitment mean score of 16 and a standard deviation of 6.96 and 32 employees were supervised by younger managers with a continuance commitment mean score of 17.54 and a standard deviation of 6.51.The results indicated that there was no significant difference in continuance commitment among employees supervised by same-age, younger or older managers $(F=0.660 ; d f=2 / 97 ; p<0.52)$. This leads to acceptance the null hypothesis.

The results also show that there were 57 employees supervised by older managers with a normative commitment mean score of 18.71 and a standard deviation of 6.29 while 11 employees were supervised by same-age managers and had a normative commitment mean score of 19.4 and a standard deviation of 6.57 and 32 employees were supervised by younger managers and had a normative commitment mean score of 18.3 and a standard deviation of 6.54 . The results indicated that there was no significant difference in normative commitment among employees supervised by same-age, younger or older managers ( $F=1.061 ; d f 2 / 97 ; p<0.35)$. This leads to acceptance the null hypothesis

The results also indicate show that there were 57 employees supervised by older managers with an overall organisational commitment mean score of 53.857 and a standard deviation of 13.97 while 11 employees were supervised by same-age managers and had an overall organisational commitment mean score of 53.5 and a standard deviation of 14.63 and 32 employees were supervised by younger managers and had a normative commitment mean score of 53.97 and a standard deviation of 14.78 . The results indicated that there was no significant difference in overall organisational commitment among employees supervised by same-age, younger or older managers ( $F=2.122$; df2/97; $p<0.13)$. This also leads to the acceptance the null hypothesis.

\subsubsection{The similarity/attraction hypotheses}

As for overall organisational commitment, no significant difference was found in organisational commitment between male employees reporting to male managers and male employees reporting to female managers $(t=1.313$; $d f=52$; $p=<0.33$ ). This leads to acceptance of the null hypothesis. As for affective and continuance commitment, a significant difference was found but not in the expected direction ( $t=-2.668 ; d f=52 ; p=<0.01$ and $t=-39.000 ; d f=19 ; p=<0.00$ ) respectively. This meant that, male employees reporting to male managers showed significantly less affective and continuance commitment than male employees reporting to female managers. Thus, though there was a significant difference between the two groups, it leads to the acceptance of the null hypothesis. It is only in relation to normative 
commitment that there was a significant difference between the two groups that is in support of the alternative commitment as expected $(t=47.393 ; d f=33 ; p=<0.00)$. The results for overall organisational commitment, affective commitment, and continuance commitment have failed to support the research hypothesis of the study but the results relating to normative commitment are in support of the research hypothesis.

As for overall organisational commitment, no significant difference was found in organisational commitment between female employees reporting to female managers and female employees reporting to male managers ( $t=1.000$; $d f=27 ; p=<0.33$ ). This leads to acceptance 0 the null hypothesis. As for affective and continuance commitment, a significant difference was found and in the expected direction ( $t=3.081 ; d f=20 ; p=<0.006$ and $t=4.021 ; d f=27 ; p=<0.004$ ). This meant that, female employees reporting to female managers showed significantly higher affective and continuance commitment than female employees reporting to male managers. This leads to acceptance of the alternative hypothesis. In normative commitment there was a significant difference between female employees reporting to female managers and those female employees reporting to male mangers but it was in an unexpected direction $(\mathrm{t}=-21.56$; $\mathrm{df}=44$; $p=<0.000$ ). This meant that, female employees reporting to female managers showed significantly less normative commitment than female employees reporting to male managers. Though there was a significant difference between the two groups this leads to acceptance of the null hypothesis. Therefore, the results for overall organisational commitment and normative commitment have failed to support the research hypothesis of the study but the results relating to affective and continuance commitment are in support of the research hypothesis.

As for overall, affective, continuance and normative commitment, no significant difference was found between employees reporting to same-age managers and those employees reporting to younger or older managers ( $t=-0.547$; $d f=98 ; p=<0.59, t=-0.113 ; d f=55.47 ; p=<0.91, t=-1.143 ; d f=65.76 ; p=<0.26$ and $t=1.235 ; d f=98 ; p=<0.220$ respectively) and these results were all not in the expected direction. This leads to the acceptance of the null hypothesis. The results for overall organisational commitment, affective commitment, continuance commitment and normative commitment have failed to support the research hypothesis of the study.

Hypotheses 1 to 3 are based on the Similarityl Attraction Paradigm of Byrne (1971). According to this theory, similarity in personal attributes, such as age and gender, is a source of interpersonal attraction. In terms of this theory, it can thus be expected that age and / or gender similarity between managers and their subordinates will result in a high level of organisational commitment on the part of the subordinates. The results relating to Hypothesis 1 (the hypothesis relating to male employees) support the theory with respect to normative commitment but not with respect to affective, continuance and overall organisational commitment. In other words, male employees reporting to male managers are higher in organisational commitment than male employees reporting female managers in relation to normative commitment only, but not in relation to affective, continuance and overall organisational commitment.

As for hypothesis 2, there are mixed result as well. This hypothesis relates to female employees and hypothesises that female employees reporting to female managers will show a higher level of organisational commitment than female employees reporting to male managers. The results show that this is the case only in relation to affective commitment and continuance commitment, but not in relation to normative and overall organisational commitment. Hypothesis 3 relates to age and postulates that employees who report to same-age managers will be higher in organisational commitment than employees who report to managers who are younger or older than them. The results of the study show completely no support for this hypothesis and therefore no support for the similarity/attraction paradigm as far as age differences are concerned. This applies to affective, continuance, normative, and overall organisational commitment. There are no significant differences in organisational commitment with respect to any of these aspects of organisational commitment. In summary, then, the result of the study partly support for the Similarity/ Attraction Paradigm in terms of gender differences. They, however, show absolutely no support for the theory in terms of age differences.

The similarity-attraction paradigm suggests that the more individuals are surrounded by others of the same age and gender at work, the higher their levels of organisational commitment is expected to be. That is, levels of organisational commitment will be higher for those employees working in same-age and same-gender dominated positions. Social scientific research has provided considerable support for tenets of the theory since the mid-1900s. Research from variety of fields such as marketing, political science, social psychology, and sociology have contributed to and these positive findings in relation to the similarity/attraction theory. The theory provides a parsimonious explanatory and predictive framework for examining how and why people are attracted to and influenced by others in their social worlds. According to studies by Berscheid and Walster (1978) and Byrne (1971) in general people are most attracted to others who share similar attitudes and there are several reasons why people prefer the company of others who espouse attitudes, especially important attitudes, which are similar to their own. Most importantly perhaps, sharing similar attitudes provides corroboration that a person is not alone in his or her belief; they might even be correct to hold the attitude in 
question. Other possible reasons suggested for why people prefer others who are similar to themselves are that (1) knowledge of similar attitudes may help people to predict others' future behaviours, providing a predictive "window" into the other's behavioural predilections, and (2) people may be more likely to assume that others who hold similar attitudes to themselves have a greater chance of being attracted to them, a "likeness begets liking" explanation. In addition to people's inclinations to be attracted to those who share similar attitudes, people are also attracted to others who manifest personality characteristics (e.g., optimism, self-esteem, shyness, conscientiousness) that are similar to their own. In fact, people may choose to associate with certain others because they are of same age or even gender.

Additionally, when it comes to the workplace setting, the study by Khalili and Asmawi (2012) showed men having higher levels of affective commitment, continuance commitment and overall organizational commitment in comparison with women. On the contrary, female employees demonstrated that they have more normative commitment to the organisation than males. Tsui, Egan and O'Reilly (1992), Wharton and Baron (1987), Kaldenberg, Beckerand and Zvonkovic, (1995), and Dodd-McCue and Wright (1996) though, in their studies found that there is no clear or significant difference between age and gender similarity and overall employee commitment at work. In other words, age and gender differences have between managers and employees no significant impact on organisational commitment.

\subsubsection{The results relating to social role or cultural hypotheses}

As for overall organisational commitment, affective, continuance and normative commitment, no significant difference was found in organisational commitment between employees reporting to male managers and those employees reporting to female managers $(t=1.49 ; d f=98 ; p=<0.14, ; t=0.44 ; d f=98 ; p=<0.66$,; $t=-0.618 ; d f=98 ; p=<0.54$ and $t=0.74 ; d f=98$; $p=<0.46$ respectively) and they are all not in the expected direction. These results lead to acceptance of the null hypothesis. The results for overall organisational commitment, affective commitment, continuance and normative commitment have failed to support the research hypothesis of the study.

As for overall organisational commitment, affective, continuance and normative commitment are concerned, no significant difference was found in organisational commitment between employees reporting to male managers and those employees reporting to female managers $(F=2.122 ; d f=2 / 97 ; p=<0.13, ; F=0.53 ; d f=2 / 97 ; p=<0.60$,; $F=0.66$; $d f=2 / 97$; $p=<0.52$ and $F=1.06 ; d f=2 / 97 ; p=<0.35$ respectively) and these results were not in an expected direction. These results also lead to acceptance of the null hypothesis and not the alternative hypothesis. In other words therefore, Hypothesis 5 results for overall organisational commitment, affective commitment, continuance and normative commitment, have failed to support the research hypothesis of the study.

Hypotheses 4 and 5 are bases on the social roles or cultural hypothesis of Eagly (1987) and Tajel and Turner (1986). These theories argue that society or culture prescribes certain roles to certain groups and that members of society generally accept these social prescriptions and become comfortable if they are adhered to and uncomfortable if they are not adhered to. Males are therefore commonly assigned the role of manager and females are assigned the role of subordinates. Similarly older members of society are assigned the role of manager and younger members are assigned the role of subordinates. These theories lead to the argument that employees reporting to a male manager would be happier and therefore more committed to their organisation than employees reporting to a female manager. Similarly employees reporting to a manager who is older than them would be happier with their manager and therefore more committed to their organisation than employees reporting to a younger or same-age manager.

The results of the study show no support at all for the social roles or cultural hypotheses whether in relation to gender or age differences between managers and their subordinates. This was surprising as $100 \%$ of the respondents in the present study were Africans. The results were unexpected from members of the African culture where society prescribes different roles to members of different groups and such roles generally coincide with power and status norms. The African society ascribes the managerial role to men and older persons while women and younger persons are supposed to be subordinates. These results may mean that the sample is westernized and this can be attributed to their relatively high levels of education since education is known to have a westernizing influence. These results may also be due to the western influence of the urban areas such as East London (or Buffalo City area) where virtually all the respondent resided and may have resided there for a long time or even for life. In summary, then, the results of this study are partially in support of the similarity / attraction paradigm and do not support the social roles theory at all.

Relating to the latter theory, social role theory recognizes the historical division in labour between females, who often assumed responsibilities of supporting roles, and males, who often assumed responsibilities of being leaders, and also between older persons who often assumed the leadership role and younger persons who often assumed the subordinate or supporting role (Eagly, 1987). As a consequence of the concomitant age and gender differences in social 
behaviour, the expectancies of men and women began to diverge (Eagly, 1987). These expectancies are transmitted to future generations and, in turn, impinge on the social behaviour of each gender (Eagly, 1987, 1997; Eagly, Wood, \& Diekman, 2000) and represent gender and age stereotypes (Williams \& Best, 1982). Accordingly, the behaviour of males and females, older, younger or same-age individuals is governed by the stereotypes of their social roles. For example, to conform to these expectations, males and older persons developed traits that manifest agency. Agency relates to traits such as the inclination to be independent, assertive, and competent (Eagly \& Karau, 1991). In contrast, females and younger persons develop traits that manifest communal or expressive behaviour, which inhibits their aggression. Communal traits entail the tendency to be friendly, unselfish, and expressive (Eagly \& Karau, 1991). Two processes underpin the connection between expectancies and behaviour. First, through socialization processes, each gender and age group learn different skills or acquire disparate qualities through socialization processes. That is, authority figures, such as teachers and parents, encourage individuals to develop the skills and qualities that will facilitate their social roles. Second, gender roles and age group differences might more directly affect the courses of action that individuals choose in a specific setting.

This theory does imply, however, that age and gender differences are flexible, because they are dependent on the immediate social role of individuals. For example, individuals occupy many roles simultaneously, all of which impinge on their behaviour. Work roles, such as leadership positions for instance, might override their age and gender roles and reduce the effects of age and gender differences (Eagly \& Johnson, 1990). Social role theory implies that individuals might question the capacity of female and younger individuals in particular positions, such as leadership roles. That is, older and male individuals often occupy leadership roles. As a consequence, individuals often assume that leadership demands the manifestations of an assertive personality. Hence, the leadership role is assumed to align the male and older individuals (Eagly, Karau, \& Makhijani, 1995; Peters, Kinsey, \& Malloy, 2004). According to Diekman, Goodfriend and Goodwin, (2004), however, gender and age differences in power are perceived to be eroding. As females and younger individuals are gaining more access to positions typically associated with power, their social role seems to be changing. This means that the working environment is now more diverse and the people both males and females, older and younger are more amenable to the changes that are taking place, and thus have no problem being led by a female or younger person.

\section{Limitations and Recommendation for Future Research}

The sample for the present study was relatively small due of financial problems and time limitation hence only 100 respondents were used out of a population of 1000 . Therefore, generalization of the findings of the study was limited. In terms of the generally accepted Raosoft Sample Size Calculator, the appropriate sample size for a population of 1000 is 278 (Raosoft Inc., 2004). Only self-administered questionnaires were used to gather data. This raises the possibility of common variance method. It results in biased correlations in organisational research. Future research should focus on the above limitations of this study. Future studies should be done using larger samples calculated with the Raosoft Sample Size Calculator (Raosoft Inc, 2004). They should also use more objective measures of the differences in age between managers and subordinates. It is absolutely necessary that the study be replicated by collecting data from numerous factories throughout the Eastern Cape to facilitate more accurate generalization of findings to a wider population. It will also be important that some future studies should use qualitative rather than quantitative methodologies. This will ensure triangulation of research results.

\section{Practical Implications of the Study}

This study was designed to investigate the applicability of two theories with important though divergent implications for workplace diversity management in the Eastern Cape. One of these theories is the similarity/attraction theory of Byrne (1971) and the other is the social roles or cultural theory of Eagly (1987). The similarity/attraction theory espouses beliefs that negate the practice of workplace diversity and instead encourages workplace homogeneity whereby managers and subordinates would have to be similar in all important personal characteristics. The social roles or cultural theory also negates the practice of workplace diversity in that managers or employees should be selected so that they fit into certain culturally accepted categories. Managers should be males, for example, and should also be older than those they manage. The results of the present study show that the applicability of these theories is either waning or non-existent in the Eastern Cape of today. The results show partial support of the similarity/attraction paradigm and absolutely no support of the social roles or cultural paradigm. 
The practical implication of this is that managers in the Eastern Cape should be encouraged to apply the principles of workforce diversity in personnel selection. They should, however, also continue to provide diversity training in the workplace so as to dispel any vestiges of resistance to diversity which may have accounted for the partial support for the similarity/attraction paradigm that was demonstrated by the results of this study.

\section{Conclusion}

The main purpose of this study was to investigate the possible effects of gender and age differences between managers and employees on organisational commitment among lower-level employees in selected factories in the Buffalo City Metropolitan area. The main objective of the study was to determine whether the level of organisational commitment of an employee will differ depending on the manager's and employee's age and gender; to test the validity of the similarityattraction paradigm of Byrne (1971), the social identity theory of Tajfel and Turner (1986), and the social roles theories of Eagly (1987) in the Eastern Cape, and to provide guidelines that could aid in both the management of organisational commitment and the assignment of employees to work teams. The study also found significant differences in the unexpected directions in affective commitment and continuance commitment between male employees supervised by male managers and male employees supervised by female managers and also between female employees supervised by female managers and female employees supervised by male managers; male employees were found to have higher levels of affective and continuance commitment when supervised by female managers and female employees were found to have a higher level of normative commitment when supervised by male managers than when supervised by female managers. This is different from what the present study hypothesized. In addition, the study showed surprising results in terms of the social or cultural hypothesis where employees supervised by male managers and older managers were not significantly different in organisational commitment to those managed by female and by younger or same-age managers. This study illustrates that people in the Buffalo City Metropolitan area have embraced diversity. Fair play and credibility in the workplace will earn managers respect regardless of their age or gender. This respect is likely to be translated into tangible organisational rewards, but this is a subject for another investigation.

\section{References}

Alagna, S. W., Reddy, D. M., \& Collins, D. L. (1982). Perceptions of functioning in mixed-sex and male medical training groups. Journal of Medical Education, 57(10), 801-803.

Barnlund, D., \& Harland, C. (1963). Propinquity and prestige as determinants of communication networks. 26, 467-479.

Berscheid, E., \& Walster, H. (1978). Interpersonal attraction. Reading, MA: Addison-Wesley.

Blanche, M. T., Durrheim, K. \& Painter, D. (2006). Research in Practice: Cape Town.

Byrne, D., Clore, G., \& Worchel, P. (1966). The effect of economic similarity - dissimilarity as determinants of attraction. Journal of Personality and Social psychology, 4, 220-224.

Byrne, D. E. (1971). The attraction paradigm. New York: Academic Press

Dessler, G. (2005). Human resource management (10 thed.) Pearson Prentice Hall

Diekman, A. B., Goodfriend, W., \& Goodwin, S. (2004). Dynamic stereotypes of power: Perceived change and stability in gender hierarchies. Sex Roles, 50, 201-215

Dodd-McCue, D. \& Wright, G. (1996). Men, women, and attitudinal commitment: the effects of workplace experiences and socialization. Human Relations, 49(8), 1065-1091

Eagly, A. H. (1987). Sex differences in social behaviour: A social role interpretation. Hillsdale, New Jersey

Eagly, A. H. (1997). Sex differences in social behaviour: Comparing social role theory and evolutionary psychology. American Psychologist, 50, 1380-1383.

Eagly, A. H., \& Johnson, B. T. (1990). Gender and leadership style: A meta-analysis. Psychological Bulletin, 108, 233-256.

Eagly, A. H., \& Karau, S. (1991). Gender and the emergence of leaders: A meta-analysis. Journal of Personality and Social Psychology, 60, 685-710.

Eagly, A. H., Karau, S., \& Makhijani, M. (1995). Gender and the effectiveness of leaders: A meta-analysis. Journal of Personality and Social Psychology, 117, 125-145.

Eagly, A. H., Wood, W., \& Diekman, A. B. (2000). Social role theory of sex differences and similarities. Mahwah, NJ: Erlbaum.

Fajana, S. (2009). HR Management in Africa: the social and economic Framework. Journal of Organisational Behaviour, 7, 80-86

Geddes, D., \& Konrad, A. M. (2003). Demographic differences and reactions to performance feedback. Human Relations, 56(12), 14851513.

Greenberg, J. \& Baron, R.A. (2010). Behaviour in organisations: Understanding and managing the human side of work.USA; Pearson education International

Hoffman, C., \& Hurst N. (1990). Gender stereotypes: Perception or rationalization? Journal of Personality and Social Psychology, 58, 
197-208.

Jackson, E. S., Joshi, A., \& Erhardt, L. N. (2003). Research on team and organizational diversity: analysis and implications. Journal of Management, 29(6), 801-830.

Kaldenberg, D., Becker, B., \& Zvonkovic, A. (1995). Work and commitment among young professionals: a study of male and female dentists. Human Relations, 48(11), 1355-1377.

Khalili, A., \& Asmawi, A. (2012). Appraising the impact of gender difference on organisational commitment: Empirical evidence from private SME in Iran. Journal of Business and Management, 7(5) 98-110

Kramer, R. (1991). Intergroup relations and organizational dilemmas: The role of categorization processes. Greenwich, CT: JAI Press.

Leedy, P. (2001). Practical Research Planning and Design. (4th ed.). New York: MacMillan Publishing Company. SAGE Press.

Meyer, J. P. \& Allen, N. J. (1997). Commitment in the Workplace: Theory, Research, and Application. Thousand Oaks: Sage Publications.

Northcraft, G., Polzer, J., Neal, M., \& Kramer, R. (1995). Diversity, social identity, and performance: Emergent social dynamics in crossfunctional teams. Stamford: JAl press.

Owoyemi, O.A., Elegbede, T. \& Gbajumo-Sheriff, M. (2011). Age diversity and the future of the workforce in Nigeria. Journal of Economics, Finance and Administrative Science 30, 1450-2275

Patten, M. L. (2004). Understanding Research Methods. (5th ed.). CA: Pyrczak Publishing.

Peters, S., Kinsey, P., \& Malloy, T. E. (2004). Gender and leadership perceptions among African Americans. Basic and Applied Social Psychology, 26, 93-101.

Raosoft, Raosoft sample size calculator, Raosoft, Inc. Seattle, WA. (2004). http://www.raosoft.com/samplesize.html. (accessed 24 Jan 2013).

Tajfel, H. (1981). Human groups and social categories: Studies in social psychology. United Kingdom: Cambridge University Press.

Taifel, H. \& Turner, J. C. (1986). The social identity theory of intergroup behaviour. Chicago: Nelson-Hall.

Triandis, H. (1960). Cognitive similarity and communication in a dyad. Human Relations, 13, 279-287.

Tsui, A. S. \& O'Reilly, C. A. (1989). Beyond simple demographic effects: The importance of relational demography in superiorsubordinate. Academy of Management Journal, 32, 402-423.

Tsui, A. S., Egan, T. D., \& O'Reilly, C. A. (1992). Being different: relational demography and organizational attachment. Administrative Science, 37,549-579.

Williams, J. E., \& Best, D. L. (1982). Measuring sex stereotypes: A thirty-nation study. Beverly Hills, CA: Sage.

Williams, K., \& O'Reilly, C. A. (1998). Demography and diversity: A review of 40 years of research. Greenwich, CT: JAI Press.

Wharton, A. S., and Baron, J. N. (1987). So happy together? The impact of gender segregation on men at work. American Sociological Review, 52, 574-587. 
